\title{
Response of Easter Lily to Preplant Incorporation of Uniconazole into the Planting Medium
}

\author{
Richard J. McAvoy \\ Department of Plant Science, U-67, 1376 Storrs Rd., University of \\ Connecticut, Storrs, CT 06269-4067 \\ Additional index words. Lilium longiflorum, growth substance
}

\begin{abstract}
Lilium longiflorum Thunb. cv. Ace grown without plant growth regulators and plants drenched with $0.5 \mathrm{mg}$ a.i. ancymidol per pot following shoot emergence were compared to plants growing in a medium containing uniconazole-impregnated amendments. Uniconazole was applied at rates of $0.18,0.018$, and $0.0018 \mathrm{mg}$ a.i. per pot using either impregnated rockwool (RW) or copolymer acrylamide acrylate (CA). Two other treatment groups received a uniconazole drench at potting $(0.018$ or 0.0018 $\mathrm{mg}$ a.i. per pot). Impregnated $\mathrm{CA}$ resulted in undesirably short lilies (i.e., plants $<1.5$ times the height of the pot) when $0.18 \mathrm{mg}$ uniconazole per pot was incorporated into the medium; effective height control was obtained with CA at $0.018 \mathrm{mg} / \mathrm{pot}$; no height control was observed at $0.0018 \mathrm{mg} /$ pot. Similarly, final height of lilies grown in medium containing uniconazole-impregnated $\mathrm{RW}$ decreased as the rate of uniconazole increased. Pre-emergence potting medium drenches with uniconazole $(0.018$ and 0.0018 mg a.i. per pot) did not significantly affect lily growth and flowering. Ancymidol drench was less effective at retarding stem length and plant height than medium incorporation of $0.18 \mathrm{mg}$ uniconazole. Flowering was not significantly affected by any treatment. Chemical names used: a-cyclopropyl-a-(4-methoxy-phenyl)-5-pyriimidine methanol(ancymidol); B-[(4-cyclophenyl)methyl]-a-(1,1-dimethylethyl) $1 \quad H$-1,2,4-triazole-1ethanol(paclobutrazol);(E)-(p-chloro-phenyl)-4,4-dimethyl-2-(1,2,4-triazol-1-yl)-1-penten3-ol(uniconazole).
\end{abstract}

Uniconazole (Sumagic, XE-1019) is a triazole class plant growth regulator (PGR) similar to paclobutrazol (Bonzi and PP333). Triazoles are extremely active, effectively retarding plant height at very low concentrations (Wilfret, 1981), and are most effective when applied to either the stem or the root zone (Barrett and Bartuska, 1982).

Paclobutrazol and ancymidol, applied as soil drenches, retard Easter lily height more effectively than foliar sprays (Gianfagna and Wulster, 1986). Furthermore, preplant Easter lily bulb dips of ancymidol retarded growth more than either drench or spray applications (Lewis and Lewis, 1981). Similarly, medium incorporation of granulated ancymidol resulted in shorter poinsettia plants than drenches that contained twice the active ingredient (Wilfret et al., 1978). However, medium-incorporation of paclobutrazol, using tablets, hydrogels, and capsules placed in

Received for publication 18 Aug. 1989. Scientific Contribution no. 1299 of the Storrs Agricultural Experiment Station, Univ. of Connecticut. This work was supported, in part, with a grant from the Univ. of Connecticut Research Foundation. The cost of publishing this paper was defrayed in part by the payment of page charges. Under postal regulations, this paper therefore must be hereby marked advertisement solely to indicate this fact. holes in the center of each pot, was less effective than soil drench applications at controlling chrysanthemum height (Sanderson et al., 1988).

Preplant methods of applying plant growth regulators are attractive because they offer potential labor savings. In addition, preplant triazole applications require less active ingredient than those applied later and persist in the soil without losing activity (Williams, 1982) or leaching (Barrett et al., 1987). Preplant medium incorporation methods may also reduce or eliminate some of the undesirable effects associated with high-dosage methods of chemical application (i. e., sprays, postemergence drenches, and high concentration bulb dips), such as thin-walled stem cells (Sanderson et al., 1975), stem collapse (Wilfret, 1981 ), lodging (Gianfagna and Wulster, 1986), and delayed flowering (Bailey and Miller, 1989; Lewis and Lewis, 1981).

The objective of this study was to determine the effects on Easter lily growth and flowering of uniformly incorporating uniconazole-impregnated rockwool and copolymer acrylamide acrylate (hydrogel) into the growing medium before planting.

Case-cooled 'Ace' Easter lily bulbs, size $8 / 9$, were obtained from a commercial vendor and planted into 1.8-liter pots on 22 Nov. 
Table 1. Growth and flowering responses of Easter lily to various PGR treatments.

\begin{tabular}{|c|c|c|c|c|c|c|}
\hline \multirow[b]{2}{*}{ Treatment ${ }^{y}$} & \multicolumn{3}{|c|}{ Interval (days) } & \multirow{2}{*}{$\begin{array}{l}\text { Floral } \\
\text { buds } \\
\text { (no.) }\end{array}$} & \multirow{2}{*}{$\begin{array}{l}\text { Final } \\
\text { stem } \\
\text { length } \\
(\mathrm{cm})\end{array}$} & \multirow{2}{*}{$\begin{array}{c}\text { Final } \\
\text { plant } \\
\mathrm{ht} \\
(\mathrm{cm})\end{array}$} \\
\hline & $\begin{array}{l}\text { To } \\
\text { emerg. }\end{array}$ & $\begin{array}{c}\text { To } \\
\text { anthesis }\end{array}$ & $\begin{array}{c}\text { Emerg. to } \\
\text { anthesis }\end{array}$ & & & \\
\hline Control & 15 & 117 & 104 & 6.9 & 37.1 & 43.1 \\
\hline \multicolumn{7}{|l|}{$\begin{array}{l}\text { Post-emergence } \\
\text { ancymidol drench }\end{array}$} \\
\hline 0.5 & 14 & 118 & 105 & 6.1 & 27.4 & 34.1 \\
\hline \multicolumn{7}{|l|}{$\begin{array}{l}\text { Pre-emergence } \\
\text { uniconazole drench }\end{array}$} \\
\hline 0.0018 & 13 & 118 & 105 & 6.5 & 35.7 & 41.3 \\
\hline 0.018 & 12 & 113 & 100 & 5.7 & 34.1 & 43.9 \\
\hline \multicolumn{7}{|l|}{$\begin{array}{l}\text { Rockwool-incorporated } \\
\text { uniconazole }\end{array}$} \\
\hline 0.0018 & 15 & 121 & 106 & 6.8 & 35.6 & 39.8 \\
\hline 0.018 & 15 & 117 & 102 & 7.3 & 30.4 & 36.5 \\
\hline 0.18 & 17 & 122 & 106 & 7.6 & 17.9 & 22.9 \\
\hline \multicolumn{7}{|l|}{$\begin{array}{l}\text { Acrylamide gel- } \\
\text { incorporated uniconazole }\end{array}$} \\
\hline 0.0018 & 15 & 117 & 102 & 7.0 & 38.0 & 45.4 \\
\hline 0.018 & 16 & 118 & 102 & 6.9 & 26.7 & 31.9 \\
\hline 0.18 & 14 & 122 & 109 & 6.6 & 17.4 & 18.9 \\
\hline Treatment effects & ** & & & & $* * * *$ & $* * * *$ \\
\hline \multicolumn{7}{|l|}{ Orthogonal contrasts } \\
\hline Control vs. others & & & & & $* * *$ & **** \\
\hline \multicolumn{7}{|l|}{ Uniconazole treatments } \\
\hline Drench vs. incorporated & **** & & & & $* * * *$ & $* * * *$ \\
\hline Rockwool linear & * & & & & $* * * *$ & **** \\
\hline Acrylamide gel quad. & & & & & $* * * *$ & $* * * *$ \\
\hline
\end{tabular}

${ }^{x}$ Each number is the mean of eight plants.

${ }^{y}$ All quantities in milligrams a.i. per pot.

$*, * *, * * * * * * *$ Significant at $P=0.05,0.01,0.001$, and 0.0001 , respectively, using the ANOVA F test; omitted contrasts were nonsignificant at $P=0.05$.

Table 2. Biweekly lily height responses to various PGR treatments.

\begin{tabular}{|c|c|c|c|c|c|c|}
\hline \multirow[b]{2}{*}{ Treatment ${ }^{y}$} & \multicolumn{6}{|c|}{ Dates of measurement } \\
\hline & $20 \mathrm{Dec}$. & 3 Jan. & 17 Jan. & 31 Jan. & 14 Feb. & 28 Feb. \\
\hline & \multicolumn{6}{|c|}{ Plant ht $(\mathrm{cm})$} \\
\hline Control & 6.5 & 13.9 & 19.5 & 23.4 & 29.4 & 37.4 \\
\hline \multicolumn{7}{|l|}{ Post-emergence } \\
\hline 0.5 & 7.1 & 16.0 & 18.1 & 19.2 & 22.6 & 28.4 \\
\hline \multicolumn{7}{|l|}{ Pre-emergence } \\
\hline uniconazole drench & $\cdot$ & & & & & \\
\hline 0.0018 & 7.2 & 14.6 & 19.8 & 23.4 & 28.4 & 35.8 \\
\hline 0.018 & 6.8 & 14.8 & 21.1 & 24.7 & 29.8 & 38.3 \\
\hline \multicolumn{7}{|l|}{$\begin{array}{l}\text { Rockwool-incorporated } \\
\text { uniconazöle }\end{array}$} \\
\hline 0.0018 & 6.1 & 13.3 & 19.4 & 22.4 & 27.1 & 34.6 \\
\hline 0.018 & 5.4 & 12.8 & 17.2 & 20.3 & 25.3 & 32.8 \\
\hline 0.18 & 5.8 & 12.4 & 15.2 & 15.2 & 16.2 & 18.7 \\
\hline \multicolumn{7}{|l|}{$\begin{array}{l}\text { Acrylamide-incorporated } \\
\text { uniconazole }\end{array}$} \\
\hline 0.0018 & 6.1 & 13.4 & 18.9 & 22.9 & 26.8 & 40.1 \\
\hline 0.018 & 6.0 & 12.6 & 16.9 & 18.5 & 23.6 & 27.8 \\
\hline 0.18 & 6.7 & 13.3 & 14.6 & 14.7 & 15.9 & 17.3 \\
\hline Treatment effects & * & $* * *$ & $* * * *$ & $* * * *$ & $* * * *$ & $* * * *$ \\
\hline \multicolumn{7}{|l|}{ Orthogonal contrasts } \\
\hline Control vs. others & & & & ** & $* * *$ & $* * *$ \\
\hline $\begin{array}{l}\text { Ancymidol vs. all } \\
\text { uniconazole }\end{array}$ & $*$ & $* * * *$ & & & & \\
\hline \multicolumn{7}{|l|}{ Uniconazole treatments } \\
\hline Drench vs. incorporated & $* * *$ & $* * *$ & $* * * *$ & $* * * *$ & $* * * *$ & $* * * *$ \\
\hline Rockwool linear & & & ** & $* * * *$ & $* * * *$ & $* * * *$ \\
\hline Actylamide gel quad. & & & $* *$ & $* * * *$ & $* * * *$ & $* * * *$ \\
\hline
\end{tabular}

${ }^{2}$ Each number is the mean of eight plants.

${ }^{y}$ All quantities are in milligrams a.i. per pot.

$*, * * * * *, * * * *$ Significant at $P=0.05,0.01,0.001$, and 0.0001 , respectively, using the ANOVA $\mathrm{F}$ test; omitted contrasts were nonsignificant at $P=0.05$.

1988. Each pot contained a 6 peat :5 loam $: 5$ perlite :1 rockwool medium (by volume) amended with (all in $\mathrm{kg} \cdot \mathrm{m}^{-3}$ ) 7.6 dolomitic limestone and 0.1 copolymer acrylamide ac- rylate. Plants were grown on a single greenhouse bench using a 20/15C day/night regime. Pots were fertilized at weekly intervals with $450 \mathrm{mg} \mathrm{N} /$ liter using a $\mathrm{Ca}\left(\mathrm{NO}_{3}\right)_{2} / \mathrm{KNO}_{3}$ mix
(15N-0P-14.9K). Fertilizer applications commenced at shoot emergence and continued until the developing buds began to tilt downward.

Lilies drenched with ancymidol $(0.5 \mathrm{mg}$ a.i. per pot when the plants were $10 \mathrm{~cm}$ tall; 3 Jan. 1989) and plants receiving no PGR were compared to plants growing in medium treated with uniconazole. Uniconazole was applied at $0.18,0.018$, and $0.0018 \mathrm{mg}$ a.i. per pot using either impregnated loose granulated rockwool (RW) or copolymer acrylamide acrylate (CA) gel. In two additional treatments, uniconazole, at 0.018 or 0.0018 mg a.i. per pot, was applied as a pre-emergence potting medium drench after the bulbs were planted. Drench applications were delivered in a $150-\mathrm{ml}$ aqueous solution. Impregnated materials were formulated by soaking RW or CA in solutions containing measured quantities of uniconazole. After all the uniconazole solution was absorbed, the material was dried (30C). In instances where impregnated RW or CA was used, the treated material was substituted in the potting medium for "the untreated component.

Two plants from each treatment were arranged in a randomized complete-block design replicated four times. Individual plant growth data were collected, including dates of emergence and initial anthesis, number of floral buds per plant, final plant height (overall height from soil line to the top of the terminal flower bud), and final stem length. Number of floral buds, final plant height, and final stem length were determined at anthesis. In addition, biweekly height measurements were recorded from 20 Dec. 1988 to 28 Feb. 1989. Data were analyzed using one-way analysis of variance procedures, and single-degree-of-freedom contrasts.

Lilies planted in medium drenched with uniconazole before planting emerged sooner than plants grown in medium containing either impregnated RW or CA (Table 1). No significant treatment effects were found with regard to days from planting to anthesis, number of days from emergence to anthesis, or final bud count (Table 1).

Significant treatment effects were observed for final stem length and final overall lily height (Table 1). Ancymidol drench and uniconazole-impregnated RW and CA at 0.018 and $0.18 \mathrm{mg} /$ pot retarded lily stem length compared to no PGR. Pre-emergence uniconazole drenches had no effect on lily height compared to incorporated uniconazole treatments. The effect of increasing rates of uniconazole incorporated in RW was linear and that of CA was quadratic on stem length and plant height. Control plants, i.e., no PGR, were taller than plants treated with ancymidol or those treated with uniconazole-impregnated RW or CA (at the two highest rates). Lilies treated with CA and RW impregnated with uniconazole at $0.18 \mathrm{mg} / \mathrm{pot}$ were shorter than those in all other treatments.

Treatment effects 'on lily height were apparent soon after plant emergence and the resulting differences increased over time (Table 2). Significant height differences were 


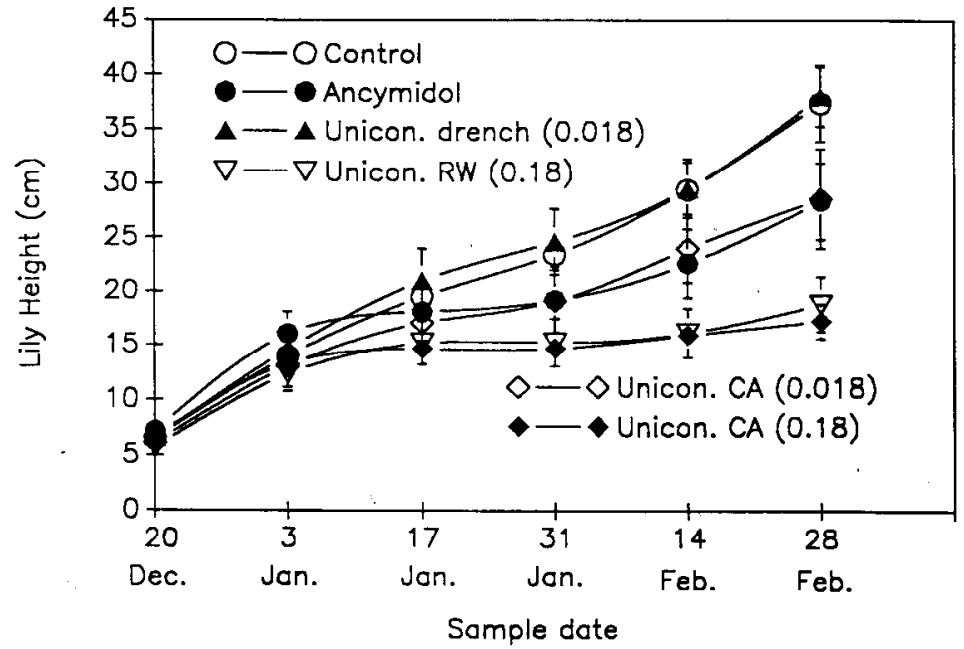

Fig. 1. Average biweekly heights of Easter lilies grown without growth regulators (control), with a post-emergence ancymidol drench $(0.5 \mathrm{mg}$ a.i. per pot), or with uniconazole applied as a preemergence potting medium drench $(0.018 \mathrm{mg}$ a.i. per pot), or incorporated into the potting medium before planting using either impregnated rockwool (RW) at $0.18 \mathrm{mg}$ a.i. per pot or copolymer acrylamide acrylate gel (CA) at $0.018 \mathrm{mg}$ and $0.18 \mathrm{mg}$ a.i. per pot. Error bars represent $95 \%$ confidence intervals.

observed already 1 month after treatment (20 Dec.). RW- and CA-incorporated uniconazole produced shorter lilies than pre-emergenec uniconazole medium drenches. Dosage effects within the RW- and CA-treated lilies became significant on 17 Jan. and continued to be significant thereafter. Significant differences were observed between control plants and the PGR-treated plants by 31 Jan.

The height of ancymidol-treated plants increased slowly from 17 Jan. to 28 Feb., compared to untreated controls, resulting in short plants (Fig. 1). The ancymidol-treated plants were more similar to the RW- and CA-treated plants and less similar to the control plants in this regard.

Commercially acceptable pot plant height is largely a matter of personal preference. However, general guidelines (Sachs et al., 1976; White, 1971) suggest an acceptable ratio of plant height to pot height of 1.5 to 2.5 (i.e., 22 to $36 \mathrm{~cm}$ for a plant in a pot $14.5 \mathrm{~cm}$ tall).
Overall, medium incorporation of uniconazole via impregnated RW and CA was effective at controlling lily height. Uniconazole incorporated into CA at $0.18 \mathrm{mg}$ a.i. per pot resulted in undesirably short plants $(<1.5$ times the height of the pot), but plants of desirable height developed when $10 \%$ of the high rate was incorporated into the medium $(0.018 \mathrm{mg}$ a.i. with CA). At $1 \%$ of the high rate $(0.0018 \mathrm{mg} /$ pot with both CA and RW) there was no effect. Pre-emergence, lowdosage uniconazole drenches did not signifcymidol drench at $0.5 \mathrm{mg}$ a.i. per pot was less effective at retarding final plant height than medium incorporation of $0.18 \mathrm{mg}$ uniconazole.

Commercially acceptable Easter lily height control can be achieved with uniconazole at rates as low as $0.018 \mathrm{mg} /$ pot when the material is uniformly incorporated into potting media before planting, without delaying anthesis or reducing bud count. The use of poticantly affect lily growth and flowering. An- ting amendments as carriers for PGRs allows a grower to enhance the physical properties of the potting media and simultaneously control growth.

\section{Literature Cited}

Bailey, D.A. and W.B. Miller. 1989. Whole-plant response of Easter lilies to ancymidol and uniconazole J. Amer. Soc. Hort. Sci. 114(3):393396.

Barrett, J.E. and C.A. Bartuska. 1982. PP333 effects on stem elongation dependent on site of application. HortScience 17(5):737-738.

Barrett, J.E., C.A. Bartuska, and T.A. Nell. 1987. Efficacy of ancymidol, daminozide, fluroprimidol, paclobutrazol, and XE-1019 when followed by irrigation. HortScicnce 22(6):12871289

Giafagna, T.J. and G.J. Wulster. 1986. Comparative effects of ancymidol and paclobutrazol on Easter lily. HortScience 21(3):463-464.

Lewis, A.J. and J.S. Lewis. 1981. Pre-plant treatment of Easter lily with ancymidol. HortScience 16(3):443. (Abstr.)

Sachs, R.M., A.M. Kofranek, and W.P. Hackett. 1976. Evaluating new pot plant species. Florist Rev. 159(4116):35-36, 80-84.

Sanderson, K.C., W.C. Martin, Jr., K.A. Marcus, and W.E. Goslin. 1975. Effects of plant growth regulators on Lilium longiflorum Thunb. cv. Georgia. HortScience 10(6):611-613.

Sanderson, K.C., W.C. Martin, Jr., and J. McGuire. 1988. Comparison of paclobutrazol tablets, drenches, gels, capsules, and sprays on Chrysanthemum growth. HortScience 23(6):1008-1009.

White, J.W. 1971. The response of 'Mid-Century' hybrid lilies to Quel, a new growth regulating chemical. Penn. Flower Growers Bul. 242:35,13

Wilfret, G.J. 1981. Height retardation of poinsettia with ICI-PP-333. HortScience 16(3):443. (Abstr.)

Wilfret, G.J., B.K. Harbaugh, and T.A. Nell. 1978. Height control of pixie poinsettia with a granular formulation of ancymidol. HortScience 13(6):701-702.

Williams, M.W. 1982. Vegetative growth control of apples with the bioregulant ICI PP333. HortScience 17(4):577. (Abstr.) 